\title{
Seasonal Characteristics of Sulfate and Nitrate in Size-segregated Particles in Ammonia-poor and -rich Atmospheres in Chengdu, Southwest China
}

\author{
Qinkai Li ${ }^{1,2}$, Zhou Yang ${ }^{3}$, Xiaodong $\mathrm{Li}^{1,2^{*}}$, Shiyuan Ding ${ }^{1,2}$, Feng Du \\ ${ }^{1}$ Institute of Surface-Earth System Science, Tianjin University, Tianjin 300072, China \\ 2 Tianjin Key Laboratory of Earth Critical Zone Science and Sustainable Development in Bohai Rim, Tianjin University, \\ Tianjin 300072, China \\ ${ }^{3}$ College of Tourism and Geographical Sciences, Tongren University, Tongren 565300, China \\ ${ }^{4}$ State Key Laboratory of Geohazard Prevention and Geoenvironment Protection, Chengdu University of Technology, \\ Chengdu 610059, China
}

\begin{abstract}
In order to determine the seasonal characteristics of water-soluble inorganic ions (WSIIs) in aerosols in urban atmospheres, size-segregated particulate matter (PM) samples were collected over a one-year period from February 2012 to January 2013 in a typical urban location, Chengdu in Southwest China, using an Andersen cascade impactor sampler. The PM mass concentrations, particularly the fine fraction, peaked during winter, and the WSIIs were more enriched in the fine fraction $(21.7 \%)$ than the coarse fraction $(9.2 \%)$. The sums of the equivalent ratios of cations $\left(\mathrm{Na}^{+}, \mathrm{NH}_{4}^{+}, \mathrm{K}^{+}, \mathrm{Mg}^{2+}\right.$, and $\left.\mathrm{Ca}^{2+}\right)$ to anions $\left(\mathrm{SO}_{4}{ }^{2-}, \mathrm{NO}_{3}{ }^{-}, \mathrm{Cl}^{-}\right.$, and $\left.\mathrm{F}^{-}\right)$indicated that the fine particles $(0.86)$ were more acidic than the coarse ones (1.60). The average $\mathrm{NH}_{4}{ }^{+} / \mathrm{SO}_{4}{ }^{2-}$ molar ratio (A/S) in the fine fraction (1.79) was much higher during winter than the other three seasons $(<1.5)$, implying a generally $\mathrm{NH}_{3}$-poor atmosphere in Chengdu; hence, the $\mathrm{NO}_{3}{ }^{-}$in the fine particles was principally formed through homogeneous reactions involving ammonia and nitric acid during winter, whereas it was heterogeneously formed during the other three seasons. Significant positive correlations were observed between the $\mathrm{A} / \mathrm{S}$ and $\mathrm{NO}_{3}{ }^{-}$molar concentrations during spring and winter; therefore, the formation of particle-phase $\mathrm{NO}_{3}{ }^{-}$may be accelerated by increased $\mathrm{A} / \mathrm{S}$ in both $\mathrm{NH}_{3}-$ poor and -rich atmospheres. Moreover, the $\mathrm{A} / \mathrm{S}$ and $\mathrm{NO}_{3}{ }^{-} / \mathrm{SO}_{4}{ }^{2-}$ molar ratios displayed negative and positive correlations during spring and winter, respectively, suggesting that the variation in atmospheric $\mathrm{NH}_{4}^{+}$(or $\mathrm{NH}_{3}$ ) during winter affected the formation of $\mathrm{NO}_{3}{ }^{-}$more strongly than that of $\mathrm{SO}_{4}{ }^{2-}$, whereas more $\mathrm{SO}_{4}{ }^{2-}$ than $\mathrm{NO}_{3}{ }^{-}$was formed in the $\mathrm{NH}_{3}$-poor atmosphere during spring, when most of the $\mathrm{NO}_{3}{ }^{-}$in the aerosols would be expected to form via heterogeneous reactions.
\end{abstract}

Keywords: Size-segregated particles; Sulfate; Nitrate; Ammonium; Chengdu.

\section{INTRODUCTION}

Atmospheric particulate matter (PM) is one of the most important components that could affect the air quality, climate change and public health (IPCC, 2013; WHO, 2013). Over last few decades, researches have been carried out in many studies worldwide, focusing on the sources and secondary formation and transformation mechanisms of PM and its effects on human health and the earth radiation balance (Seinfeld, 1998; Dockery et al., 1993; Huang et al., 2014; Wang et al., 2016; Yao et al., 2018). Atmospheric PM can be derived from both anthropogenic and natural sources, and can also be formed in the atmosphere from secondary

\footnotetext{
${ }^{*}$ Corresponding author.

Tel.: +86 022-83614909; Fax: +86 022-27405053

E-mail address: xiaodong.li@tju.edu.cn
}

processes (oxidation of gaseous species), and the particle size ranges from a few nanometers to several tens of micrometers (Zhang et al., 2015; Wang et al., 2017a) that plays a critical role in their environmental and human health effects (Kulmala et al., 2004; West et al., 2016; Tian et al., 2018; Klimont et al., 2017).

The water-soluble inorganic ions (WSIIs) including anions $\left(\mathrm{SO}_{4}{ }^{2-}, \mathrm{NO}_{3}{ }^{-}, \mathrm{Cl}^{-}\right.$and $\left.\mathrm{F}^{-}\right)$and cations $\left(\mathrm{Ca}^{2+}, \mathrm{Mg}^{2+}, \mathrm{Na}^{+}, \mathrm{K}^{+}\right.$ and $\mathrm{NH}_{4}{ }^{+}$), often account for a major fraction of atmospheric PM mass, play a vital role in scattering incoming solar radiation and altering cloud properties and thus enhance the indirect radiative forcing (Seinfeld and Pandis, 1998; Zhao et al., 2011). Recent studies have indicated that the WSII fraction in PM varies not only with time and space but also with the particle size, which could provide key information for interpreting the sources and formation mechanisms of the PM (Zhang et al., 2008; Huang et al., 2016; Wu et al., 2017). To a large extent, WSIIs determines the particle acidity and hygroscopicity, which could control the rates of 
heterogeneous chemical reactions (He et al., 2012; Hennigan et al., 2015; Wang et al., 2016; Weber et al., 2016; Tian et al., 2018). In general, the $\mathrm{SO}_{4}{ }^{2-}, \mathrm{NO}_{3}{ }^{-}$and $\mathrm{NH}_{4}{ }^{+}$(together called $S N A$ ) are dominant WSIIs in fine-mode $\mathrm{PM}$ and exist primarily in the forms of $\left(\mathrm{NH}_{4}\right)_{2} \mathrm{SO}_{4}, \mathrm{NH}_{4} \mathrm{HSO}_{4}$ and $\mathrm{NH}_{4} \mathrm{NO}_{3}$ and expected to be formed through the neutralization reactions between acids (i.e., $\mathrm{H}_{2} \mathrm{SO}_{4}$ and $\mathrm{HNO}_{3}$ ) and $\mathrm{NH}_{3}$ in gas phase (Yao et al., 2002; Lin et al., 2006; Lin and Cheng, 2007; Wu et al., 2018). As $\mathrm{NH}_{3}$ could neutralize the $\mathrm{H}_{2} \mathrm{SO}_{4}$ to $\left(\mathrm{NH}_{4}\right)_{2} \mathrm{SO}_{4}$ or $\mathrm{NH}_{4} \mathrm{HSO}_{4}$ (Wang et al., 2005; Vieira-Filho et al., 2016), the $\mathrm{NH}_{4}{ }^{+} / \mathrm{SO}_{4}{ }^{2-}(\mathrm{A} / \mathrm{S})$ molar ratio of 1.5 can be considered as an indicator in determining the formation pathways of $\mathrm{NO}_{3}{ }^{-}$ in the atmosphere (Pathak et al., 2004, 2009). In "excess $\mathrm{NH}_{4}{ }^{+}$" (i.e., $\mathrm{A} / \mathrm{S}>1.5, \mathrm{NH}_{3}$-rich) environment, $\mathrm{NO}_{3}{ }^{-}$is supposed to be formed homogeneously whereas in "deficient $\mathrm{NH}_{4}{ }^{+}$" (i.e., $\mathrm{A} / \mathrm{S}<1.5, \mathrm{NH}_{3}$-poor) environment, it tends to be formed via heterogeneous reactions, the $\mathrm{NH}_{3}$ is insufficient to neutralize the $\mathrm{HNO}_{3}$ (He et al., 2012; Behera et al., 2013; Tian et al., 2018). However, the current available studies on $\mathrm{A} / \mathrm{S}$ values focused mainly on fine-mode particles, since the $\mathrm{NH}_{4}{ }^{+}$could be of less importance on coarse particles (Wu et al., 2017; Jiang et al., 2018). Recently, atmospheric $\mathrm{NH}_{3}$ has become a public concern for its potential in facilitating the formation of secondary aerosol, but it is yet to be regulated in many regions around the world. Therefore, to better understand the formation of $\mathrm{SO}_{4}{ }^{2-}$ and $\mathrm{NO}_{3}{ }^{-}$in both fine and coarse $\mathrm{PM}$, long-term observations of WSIIs in PM is necessary, despite the recent progress, including their seasonal characteristics, which could help in identifying the PM sources and elucidating the transformation mechanisms of heavy haze formation over megacities in China (Wang et al., 2017b; Zou et al., 2018).

Chengdu, the capital city of Sichuan Province, is located at the western part of the Sichuan Basin. Due to the blocked terrain and relatively stagnant weather in Sichuan Basin, the pollutants emitted from local sources are retained for longer time compared to the other areas of China, and frequently results heavy air pollution (haze) events at Chengdu (Ning et al., 2018). Besides, the increase in energy consumption due to rapid industrialization and urbanization over the past few decades should be significantly contributing to the severe urban haze in Chengdu. However, the studies on characterization of PM and the sources of haze in Chengdu are limited to short-term observations (e.g., the dust and biomass burning) and model simulations (Chen and Xie, 2013; Tao et al., 2013; Tian et al., 2013; Wang et al., 2013b; Tao et al., 2014; Chen et al., 2015; Shi et al., 2017). In this study, we focused on identification of PM sources through the measurements of major WSIIs in size-segregated particles collected over a one-year period in Chengdu, Southwest China. We discuss the seasonal characteristics and formation mechanisms of aerosol $\mathrm{SO}_{4}{ }^{2-}$ and $\mathrm{NO}_{3}{ }^{-}$in the $\mathrm{NH}_{3}$-poor and -rich atmosphere at Chengdu.

\section{MATERIALS AND METHODS}

\section{Study Location}

Chengdu is situated in Sichuan Basin with the QinghaiTibet Plateau on the west, Qinling Mountains and the Loess Plateau on the north, Hunan and Hubei Province on the east, and the Yunnan-Guizhou Plateau on the south. The climate of Sichuan Basin is characterized by subtropical monsoon and temperate oceanic climate (Chen and Xie, 2014; Li et al., 2015). The weather is categorized into four distinct seasons with the temperature ranging from $5^{\circ} \mathrm{C}$ in winter to $26^{\circ} \mathrm{C}$ in summer. Average annual precipitation is $918 \mathrm{~mm}$ with high abundance and frequency in summer to autumn (i.e., from June to November) period than in winter to spring (i.e., from December to May).

As one of the most crowded regions in Sichuan Basin, Chengdu has a permanent population of more than 14 million, and the population density is about 964 people per square kilometer. Like many other megacities in China, Chengdu is growing at an unprecedented pace with an urbanization rate of $60.2 \%$ in 2012 , and it had the eighth largest gross domestic production in China. According to the statistical yearbook of Chengdu for 2013 (Chengdu Bureau of Statistics), the total vehicle number exceeded 3.0 million by the end of 2012, which is the second highest number among all Chinese cities. The industrial areas are mostly located in the northern suburbs of city, about $20 \mathrm{~km}$ away from the sampling site. The total energy consumption of Chengdu increased from 24 million tons of standard coal equivalent to 44.4 million tons of standard coal equivalent between 2005 and 2012, according the statistics from the World Resources Institute (http://www.wri.org).

\section{Sampling}

Size-segregated atmospheric particle sampling was performed using an eight-stage Andersen cascade impactor air sampler (AN-200; SIBATA, Japan) in Chengdu, Southwest China. The sampler was placed on the rooftop of a building (15 $\mathrm{m}$ above ground level) in Chengdu University of Technology (CDUT) campus $\left(30^{\circ} 40^{\prime} 40^{\prime \prime} \mathrm{N}, 104^{\circ} 08^{\prime} 30^{\prime \prime} \mathrm{E}\right)$, located at Chenghua district in the urban northeastern part of Chengdu. The cut points of the sampler were set as 11, 7.0, $4.7,3.3,2.1,1.1,0.65$ and $0.43 \mu \mathrm{m}$, and the samples were collected from 15 February 2012 to 21 January 2013 at flow rate of $28.3 \mathrm{~L} \mathrm{~min}^{-1}$ with a frequency of 4-8 days for each sample, in order to ensure adequate particle load for reliable chemical analysis. Before sampling, the quartz fiber filters (Ø80 mm, Tissuquartz 2500QAT-UP; Pallflex) were preheated in a muffle furnace at $450^{\circ} \mathrm{C}$ for $6 \mathrm{~h}$, and wrapped in aluminum foil individually after sampling, then sealed in airtight polyethylene bags and stored at $-18^{\circ} \mathrm{C}$ until analysis. In this study, a total of 108 filter samples were obtained, and field blanks were sampled without sucking air for $10 \mathrm{~min}$ and treated the same way as particle samples.

\section{Chemical and Statistical Analyses}

Filters were gravimetrically weighed before and after the sampling, after $24 \mathrm{~h}$ equilibration at constant temperature $\left(20-23^{\circ} \mathrm{C}\right)$ and relative humidity $(35-45 \%)$, using a Sartorius MC5 electronic microbalance with a sensitivity of $\pm 1 \mu \mathrm{g}$ (Sartorius; Göttingen, Germany). The weight difference between before and after sampling was considered as particle weight and the mass concentration was calculated by dividing it with the sample air volume.

Half of the sample filters was cut into pieces, soaked in 
$15 \mathrm{~mL}$ deionized water (18.2 M 2 ; Milli-Q, USA) and ultrasonically extracted three times (i.e., $10 \mathrm{~min}$ each). After the extraction, the solutions were then filtered through syringe filters $(0.22 \mu \mathrm{m}$; Millipore) and stored in high-density polyethylene bottles for subsequent WSII analysis. Anions $\left(\mathrm{F}^{-}, \mathrm{Cl}^{-}, \mathrm{NO}_{3}{ }^{-}\right.$and $\left.\mathrm{SO}_{4}{ }^{2-}\right)$ and cations $\left(\mathrm{Na}^{+}, \mathrm{K}^{+}, \mathrm{Ca}^{2+}\right.$ and $\mathrm{Mg}^{2+}$ ) were measured using ion chromatography (ICS-90; Dionex, USA) and inductively coupled plasma optical emission spectrometry (ICP-OES; MPX, USA), respectively, and the $\mathrm{NH}_{4}{ }^{+}$was measured with a SKALAR continuous flow analyzer ( $\mathrm{San}^{++}$Automated Wet Chemistry Analyzer; Holland). The instrument detection limits are $0.02 \mathrm{mg} \mathrm{L}^{-1}$ for anions and $0.005 \mathrm{mg} \mathrm{L}^{-1}$ for cations and NH4+ (Xiao and Liu, 2004; Yang et al., 2015). Standard reference materials produced by the National Institute of Metrology in China were used for quality assurance, and the measurement uncertainties for different ion concentrations in this study were typically less than $5 \%$ based on replicate analysis of standards. No targeted ions were detected in the field blank.

To compare the results obtained in size-segregated particles among the four seasons, Student's $t$-test was performed by assuming equal variance in two populations at a $95 \%$ confidence level with SPSS Statistics (version 19.0; IBM Corp., Armonk, NY, USA). Correlation analysis was also performed among concentration data and molar data across the study period. Statistically significant difference was set at $p$ values less than 0.05 unless otherwise stated.

\section{RESULTS AND DISCUSSION}

\section{Aerosol Particle Mass Concentrations}

Since the Anderson impactor sampler does not have a $2.5 \mu \mathrm{m}$ cut point, the diameter of $2.1 \mu \mathrm{m}$ is defined as the boundary for fine and coarse particles in this study (Fig. 2). The annual mean concentrations of $\mathrm{PM}_{2.1}$ and $\mathrm{PM}_{11}$ are $125.9 \pm 56.1 \mu \mathrm{g} \mathrm{m}^{-3}$ and $224.5 \pm 83.6 \mu \mathrm{g} \mathrm{m}^{-3}$, respectively. They were significantly higher than the annual $\mathrm{PM}_{2.5}$ and
$\mathrm{PM}_{10}$ limits of both Chinese National Ambient Air Quality Standards (35 and $70 \mu \mathrm{g} \mathrm{m}^{-3}$; Grade II of GB3095-2012) and the WHO air quality guidelines (10 and $20 \mu \mathrm{g} \mathrm{m}^{-3}$; WHO, 2006). Nevertheless, these values are comparable with other studies synchronously conducted at Chengdu (120.4 and $\left.195.5 \mu \mathrm{g} \mathrm{m}^{-3}\right)$, but higher than those reported at Wuhan $(89.6$ and $134.9 \mu \mathrm{g} \mathrm{m}^{-3}$ ), Shanghai (103.1 and $149.2 \mu \mathrm{g} \mathrm{m}^{-3}$ ), and Guangzhou (97.5 and $144.4 \mu \mathrm{g} \mathrm{m}^{-3}$ ) and lower than those reported at Xi'an (140.9 and $\left.257.8 \mu \mathrm{g} \mathrm{m}^{-3}\right)$ over the parallel periods (Wang et al., 2006; Shi et al., 2017; Wang et al., 2013b; Wang et al., 2015; Wang et al., 2017a), indicating that the PM loading is high at Chengdu.

The $\mathrm{PM}_{11}$ mass concentration peaked in March (378.4 $\mu \mathrm{g} \mathrm{m}^{-3}$ ) followed by February $\left(371.4 \mu \mathrm{g} \mathrm{m}^{-3}\right)$. However, the $\mathrm{PM}_{2.1} / \mathrm{PM}_{11}$ ratio was significantly higher in February $(0.70)$ than that in March (0.54) (Fig. 1), despite the fact that the $\mathrm{PM}_{11}$ mass concentration was comparable, implying that the sources and/or formation pathways of the PM were different in these two months (Tao et al., 2013; Wang et al., 2013; Chen et al., 2015). An increase trend of the $\mathrm{PM}_{2.1} / \mathrm{PM}_{11}$ ratio was observed during the campaign from spring to winter, except for two anomalous high values in May and July, which might be caused by the crop residue burning around Chengdu (Tao et al., 2013; Chen and Xie, 2014). Seasonally, the $\mathrm{PM}_{2.1} / \mathrm{PM}_{11}$ ratio in winter $(0.65 \pm 0.04)$ is significantly higher than that in the other three seasons, which might be caused by the enhanced emission from anthropogenic activities (e.g., bulk coal and biomass burning for civil heating) and poor air diffusion condition due to low temperature and wind speed, which promote the fine particles' formation and accumulation (Table 1) (Ning et al., 2018).

\section{Size Distribution of WSIIs}

Total WSIIs of $\mathrm{PM}_{2.1}$ ranged from 10.5 to $68.9 \mu \mathrm{g} \mathrm{m}^{-3}$, with an annual average of $27.6 \pm 19.8 \mu \mathrm{g} \mathrm{m}^{-3}$, and accounted for $20.7 \%$ of the $\mathrm{PM}_{2.1}$ mass, whereas the annual average of WSIIs

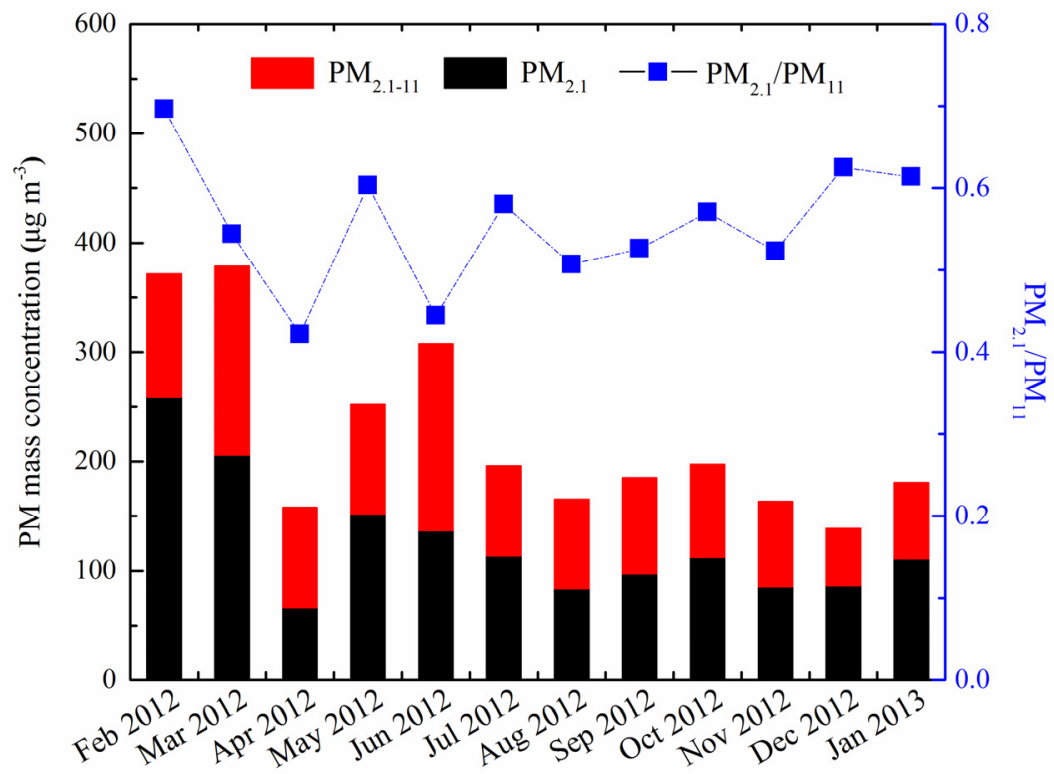

Fig. 1. Time series of $\mathrm{PM}_{2.1}$ and $\mathrm{PM}_{2.1-11}$ mass concentrations and $\mathrm{PM}_{2.1} / \mathrm{PM}_{11}$ mass ratios. 
Table 1. Meteorological records during each sampling month.

\begin{tabular}{llllll}
\hline Sampling periods & $\mathrm{T}^{\mathrm{a}}\left({ }^{\circ} \mathrm{C}\right)$ & $\mathrm{RH}^{\mathrm{b}}(\%)$ & $\mathrm{WS}^{\mathrm{c}}\left(\mathrm{km} \mathrm{h}^{-1}\right)$ & $\mathrm{P}^{\mathrm{d}}(\mathrm{hPa})$ & Visibility $(\mathrm{km})$ \\
\hline 15-21 Feb 2012 & $6.57 \pm 1.4$ & $81.0 \pm 5.5$ & $5.4 \pm 3.3$ & $1021.0 \pm 4.6$ & $3.6 \pm 0.5$ \\
11-19 Mar 2012 & $14.0 \pm 3.4$ & $67.2 \pm 5.1$ & $4.4 \pm 1.1$ & $1011.4 \pm 5.8$ & $4.8 \pm 1.1$ \\
11-18 Apr 2012 & $18.1 \pm 1.0$ & $62.8 \pm 9.3$ & $7.0 \pm 2.1$ & $1009.0 \pm 1.5$ & $7.6 \pm 2.0$ \\
14-18 May 2012 & $23.4 \pm 1.8$ & $53.2 \pm 7.0$ & $5.0 \pm 2.1$ & $1007.6 \pm 3.6$ & $7.2 \pm 2.4$ \\
18-23 Jun 2012 & $24.0 \pm 1.7$ & $79.5 \pm 7.6$ & $2.7 \pm 0.5$ & $1002.8 \pm 2.1$ & $4.2 \pm 1.6$ \\
15-22 Jul 2012 & $24.1 \pm 1.7$ & $88.0 \pm 3.9$ & $4.6 \pm 1.9$ & $1003.3 \pm 2.1$ & $5.1 \pm 1.8$ \\
15-22 Aug 2012 & $27.1 \pm 2.5$ & $74.4 \pm 8.9$ & $5.9 \pm 1.6$ & $1006.1 \pm 3.5$ & $8.1 \pm 1.5$ \\
13-18 Sep 2012 & $19.3 \pm 1.9$ & $81.8 \pm 11.4$ & $5.3 \pm 2.6$ & $1014.5 \pm 1.4$ & $4.6 \pm 1.5$ \\
9-15 Oct 2012 & $18.3 \pm 1.4$ & $90.0 \pm 5.5$ & $3.3 \pm 2.8$ & $1015.3 \pm 3.1$ & $4.7 \pm 0.8$ \\
15-24 Nov 2012 & $12.2 \pm 1.6$ & $68.8 \pm 10.5$ & $4.6 \pm 1.4$ & $1014.9 \pm 4.2$ & $6.2 \pm 2.4$ \\
9-17 Dec 2012 & $9.67 \pm 0.7$ & $85.0 \pm 6.4$ & $4.1 \pm 1.4$ & $1015.0 \pm 3.1$ & $3.1 \pm 1.3$ \\
15-21 Jan 2013 & $7.57 \pm 0.5$ & $77.3 \pm 9.5$ & $4.6 \pm 1.8$ & $1019.4 \pm 5.8$ & $3.1 \pm 1.4$ \\
\hline
\end{tabular}

The meteorological data can be found at https://www.wunderground.com/. ${ }^{\mathrm{a}}$ Temperature; ${ }^{\mathrm{b}}$ Relative Humidity; ${ }^{\mathrm{c}}$ Wind Speed; ${ }^{\text {d }}$ Sea-level Pressure.

in $\mathrm{PM}_{2.1-11}$ was $9.6 \pm 7.6 \mu \mathrm{g} \mathrm{m}^{-3}$ (range: $4.4-28.6 \mu \mathrm{g} \mathrm{m}^{-3}$ ) and accounted for about $9.2 \%$ of $\mathrm{PM}_{2.1-11}$, which indicates that the WSIIs are highly enriched in fine particles. Furthermore, the total WSIIs in $\mathrm{PM}_{2.1}$ was the highest in winter ( $40.5 \pm$ $\left.24.8 \mu \mathrm{g} \mathrm{m}^{-3}\right)$, followed by spring $\left(39.6 \pm 22.9 \mu \mathrm{g} \mathrm{m}^{-3}\right)$, summer $\left(17.4 \pm 7.5 \mu \mathrm{g} \mathrm{m}^{-3}\right)$ and autumn $\left(12.7 \pm 0.9 \mu \mathrm{g} \mathrm{m}^{-3}\right)$, while the WSIIs in $\mathrm{PM}_{2.1-11}$ was higher in spring (16.9 \pm $\left.10.2 \mu \mathrm{g} \mathrm{m}^{-3}\right)$, followed by winter $\left(10.0 \pm 9.4 \mu \mathrm{g} \mathrm{m}^{-3}\right)$, summer $\left(6.3 \pm 1.8 \mu \mathrm{g} \mathrm{m}^{-3}\right)$ and autumn $\left(5.1 \pm 0.4 \mu \mathrm{g} \mathrm{m}^{-3}\right)$. It is noteworthy that the total WSIIs in both fine and coarse particles reduced sharply in summer and autumn at Chengdu that can be attributed largely to high rainfall during monsoon seasons (Xiao and Liu, 2004; Pan et al., 2017). The content of WSIIs in fine fraction in winter is comparable to that in spring, whereas in coarse fraction, it was significantly higher in spring than that in winter, suggesting their enhanced contribution from biomass burning and/or dust storms in spring (Tao et al., 2013; Wang et al., 2013; Chen et al., 2015; Tian et al., 2016b; Shi et al., 2017). The abundances of WSIIs in $\mathrm{PM}_{2.1}$ were: $\mathrm{SO}_{4}{ }^{2-}>\mathrm{NO}_{3}{ }^{-}>\mathrm{NH}_{4}{ }^{+}>\mathrm{Cl}^{-}>\mathrm{Mg}^{2+}$ $>\mathrm{K}^{+}>\mathrm{Ca}^{2+}>\mathrm{Na}^{+}>\mathrm{F}^{-}$, while in $\mathrm{PM}_{2.1-11}$ they were: $\mathrm{SO}_{4}{ }^{2-}>$ $\mathrm{Ca}^{2+}>\mathrm{NO}_{3}^{-}>\mathrm{Cl}^{-}>\mathrm{NH}_{4}^{+}>\mathrm{Mg}^{2+}>\mathrm{K}^{+}>\mathrm{Na}^{+}>\mathrm{F}^{-}$(Table 2), indicating that $\mathrm{SO}_{4}{ }^{2-}$ and $\mathrm{NO}_{3}{ }^{-}$are dominant species in $\mathrm{PM}$ at Chengdu. The discrepancies in the order of major ions' abundances in fine and coarse fractions might have been driven by the differences in their formation pathways ( $\mathrm{Li}$ and Shao, 2009; Liu et al., 2015; Li et al., 2018). Generally, $\mathrm{SO}_{4}{ }^{2-}, \mathrm{NO}_{3}{ }^{-}$, and $\mathrm{NH}_{4}{ }^{+}$are formed by chemical reactions between the gas-phase precursors such as $\mathrm{NO}_{x}, \mathrm{SO}_{2}$, and $\mathrm{NH}_{3}$ in the atmosphere, however, the relatively high abundances of $\mathrm{SO}_{4}{ }^{2-}, \mathrm{Ca}^{2+}$, and $\mathrm{NO}_{3}{ }^{-}$and low abundance of $\mathrm{NH}_{4}{ }^{+}$in the coarse fraction indicate that they were mostly formed through heterogeneous reactions of the gas-phase precursors on pre-existing particles and/or derived from soil dust (Lin and Cheng, 2007; Tao et al., 2013; Chen et al., 2015; Shi et al., 2017) (Table 1).

Size distributions of major ions in each season are plotted as $\mathrm{dC} / \mathrm{d} \log \mathrm{Dp}$ as a function of $\mathrm{Dp}$ (diameter of particles) and showed in Fig. 2. $\mathrm{SO}_{4}{ }^{2-}$ showed a unimodal distribution with a peak at $0.65-1.1 \mu \mathrm{m}$. $\mathrm{SO}_{4}{ }^{2-}$ can be directly emitted into the atmosphere from primary sources like burning processes and
Table 2. The mean and S.D. of WSIIs' mass concentrations in $\mathrm{PM}_{2.1}$ and $\mathrm{PM}_{2.1-11}$.

\begin{tabular}{llllll}
\hline \multirow{2}{*}{ WSIIs $\left(\mu \mathrm{g} \mathrm{m}^{-3}\right)$} & \multicolumn{2}{c}{$\mathrm{PM}_{2.1}$} & & \multicolumn{2}{c}{$\mathrm{PM}_{2.1-11}$} \\
\cline { 2 - 3 } \cline { 5 - 6 } & Mean & S.D. & & Mean & S.D. \\
\hline $\mathrm{SO}_{4}{ }^{2-}$ & 13.2 & 9.76 & & 3.22 & 2.78 \\
$\mathrm{NO}_{3}{ }^{-}$ & 6.08 & 4.17 & & 1.91 & 1.65 \\
$\mathrm{Cl}^{-}$ & 1.58 & 1.21 & & 0.61 & 0.33 \\
$\mathrm{~F}^{-}$ & 0.01 & 0.02 & & 0.15 & 0.19 \\
$\mathrm{Ca}^{2+}$ & 0.56 & 0.21 & & 2.15 & 1.54 \\
$\mathrm{Mg}^{2+}$ & 0.92 & 1.66 & & 0.45 & 0.92 \\
$\mathrm{Na}^{+}$ & 0.30 & 0.47 & & 0.19 & 0.25 \\
$\mathrm{~K}^{+}$ & 0.90 & 0.50 & & 0.35 & 0.15 \\
$\mathrm{NH}_{4}{ }^{+}$ & 4.01 & 4.39 & & 0.58 & 0.82 \\
\hline
\end{tabular}

${ }^{a}$ S.D.: Standard Deviation.

can also be produced in the atmosphere by homogeneous oxidation reactions of reduced sulfur species (e.g., $\mathrm{SO}_{2}$ or DMS) with $\mathrm{OH}$ radical, $\mathrm{H}_{2} \mathrm{O}_{2}$ and ozone (Seinfeld and Pandis, 1998; Guo et al., 2010). On the other hand, it can also be formed by heterogeneous reactions including the aqueousphase reactions (e.g., cloud processes) (Guo et al., 2010; Huang et al., 2018). In spring, in addition to a major peak at $0.65-$ $1.1 \mu \mathrm{m}, \mathrm{SO}_{4}{ }^{2-}$ showed two minor peaks at 2.1-4.7 and 7.0$11 \mu \mathrm{m}$, which indicate that it should have been significantly produced by both homogeneous and heterogeneous reactions in Chengdu (Zhuang et al., 1999). Interestingly, $\mathrm{NO}_{3}{ }^{-}$ showed unimodal distribution in warm (i.e., spring and summer) and bimodal distribution in cold (autumn and winter) periods (Fig. 2). Such differences imply that $\mathrm{NO}_{3}{ }^{-}$sources and/or formation processes might be different during warm and cold periods in Chengdu. $\mathrm{NO}_{3}{ }^{-}$can be formed more favorably through gas-to-particle conversion at lower temperature, and it might also under the influence of sand storms occurred during dry seasons. In addition, contrary to $\mathrm{SO}_{4}{ }^{2-}, \mathrm{NO}_{3}{ }^{-}$showed a larger peak in winter than that in spring (Fig. 2). In fact, ambient temperature and relative humidity are quite different during spring and winter, which might have greatly impacted their transformation mechanisms (Huang et al., 2018). Aerosol $\mathrm{NH}_{4}{ }^{+}$is generally formed from the alkaline gas (i.e., $\mathrm{NH}_{3}$ ) by reacting with acidic species 

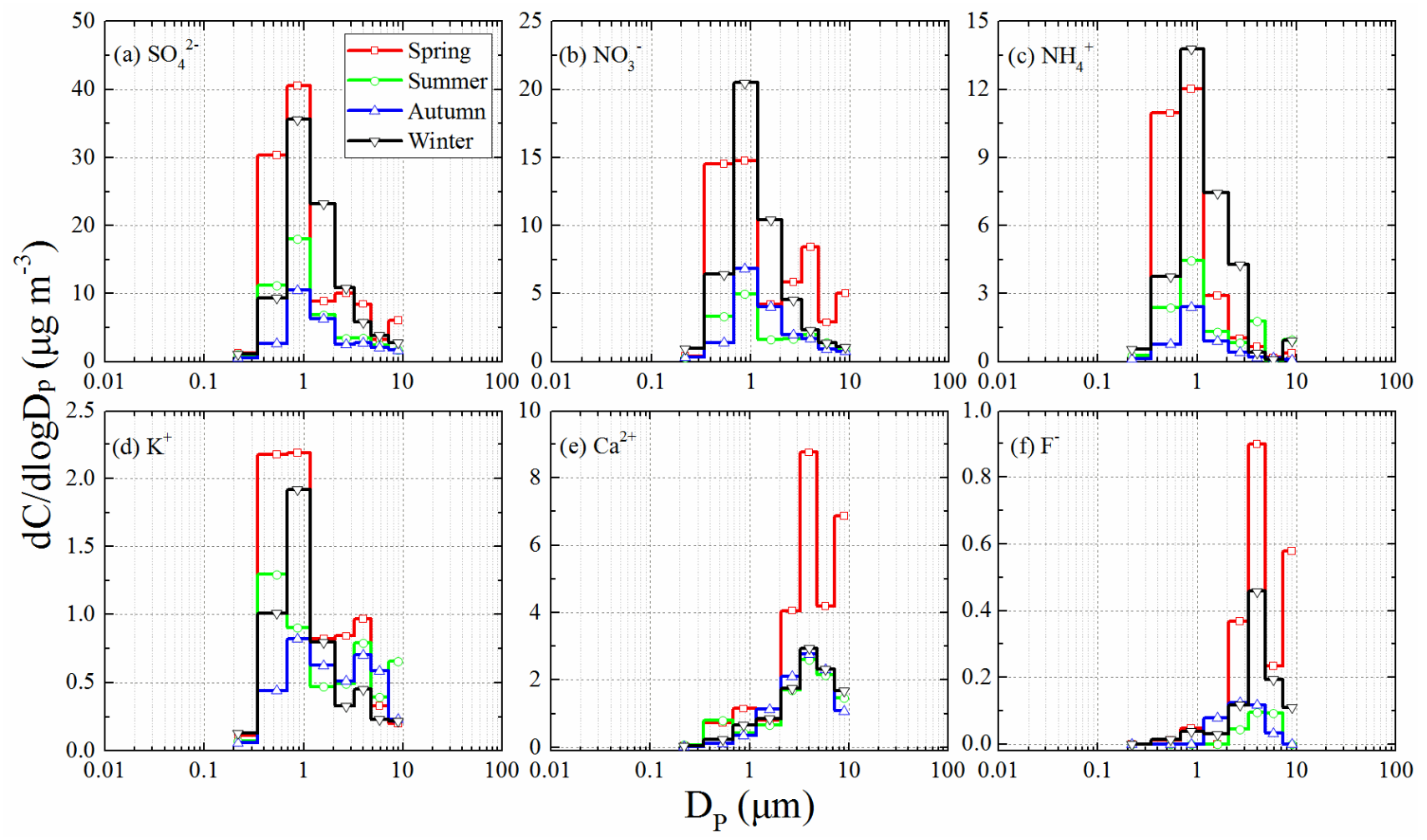

Fig. 2. The distributions of major WSIIs over four seasons, which showed $d C / d \operatorname{logDp}$ value as a function of Dp (diameter of particles). The included WSIIs are: (a) $\mathrm{SO}_{4}{ }^{2-}$, (b) $\mathrm{NO}_{3}^{-}$, (c) $\mathrm{NH}_{4}{ }^{+}$, (d) $\mathrm{K}^{+}$, (e) $\mathrm{Ca}^{2+}$, and (f) $\mathrm{F}^{-}$.

(e.g., $\mathrm{H}_{2} \mathrm{SO}_{4}, \mathrm{HNO}_{3}$ and $\mathrm{HCl}$ ). It was largely enriched in fine-mode particles and peaked at $0.65-1.1 \mu \mathrm{m}$, consistent with $\mathrm{SO}_{4}{ }^{2-}$ and $\mathrm{NO}_{3}{ }^{-}$(Fig. 2(c)), suggesting that $\mathrm{NH}_{4} \mathrm{NO}_{3}$, $\left(\mathrm{NH}_{4}\right)_{2} \mathrm{SO}_{4}$ and/or $\mathrm{NH}_{4} \mathrm{HSO}_{4}$ are the main forms of these ions in Chengdu PM (Wang et al., 2013; Huang et al., 2016). The seasonal distributions of $\mathrm{NH}_{4}{ }^{+}$could mainly be affected by the meteorological conditions. For example, ambient temperature can impact both the release of $\mathrm{NH}_{3}$ and $\mathrm{NH}_{4}{ }^{+}$ phase portioning, and wet deposition of $\mathrm{NH}_{4}{ }^{+}$should be significant in summer and autumn due to high rainfall, whereas in winter, the conversion and accumulation of $\mathrm{NH}_{4}{ }^{+}$ might be exacerbated due to low temperature and wind speed and frequent fog events (Pan et al., 2017; Ning et al., 2018).

$\mathrm{K}^{+}$shows bimodal distribution with a large peak in fine particles and exhibited the highest abundance in spring (Fig. 2(d)), probably due to enhanced biomass burning emissions. Generally, the particle $\mathrm{K}^{+}$is regarded as a good tracer for biomass burning emission into the atmosphere. Chen and Xie (2014) reported high concentrations of finemode $\mathrm{K}^{+}$during biomass burning episode occurred in spring at urban Chengdu. While during other seasons, it can be inferred that the fumes of biomass burning by domestic use (e.g., daily cooking) at rural areas are responsible for the fine-mode $\mathrm{K}^{+}$. $\mathrm{Ca}^{2+}$ showed a bimodal distribution with the peaks in coarse-mode particles $(3.3-4.7$ and 7.0-11.0 $\mu \mathrm{m})$ in each and every season (Fig. 2(e)), and showed extremely high loading in spring, which can be attributed for local fugitive dust due to the strong winds (Table 1) as well as long-range transported dust sands from arid or semi-arid areas of North China (Tao et al., 2013). Resuspension of soil dust, marine aerosols, and material from volcanic eruptions are the major natural pathways of particle $\mathrm{F}^{-}$entering the atmosphere, while aluminum smelting, coal combustion and brick manufacturing are its main anthropogenic sources (Carpenter, 1969; Kalinić et al., 1997). A recent study also showed that biomass burning could be one of the major sources of fine particle $\mathrm{F}_{-}$(Jayarathne et al., 2014). Interestingly, the size distribution of $\mathrm{F}^{-}$was similar to that of $\mathrm{Ca}^{2+}$, i.e., peaked at 3.3-4.7 and 7.0-11.0 $\mu \mathrm{m}$ in spring (Fig. 2(f)). Such size distribution indicates that they both were probably derived from the common sources, such as the local fugitive cement dust and/or the gaseous fluoride (i.e., hydrogen fluoride) might have been heterogeneously reacted with coarse-mode $\mathrm{Ca}^{2+}$. However, it is difficult to provide a definite conclusion from this study due to limited data, a subject of future research.

\section{Particle Acidity in Urban Chengdu}

Particle acidity is an important parameter that could influence the concentration, chemical composition, and toxicity of PM (Weber et al., 2016). Nevertheless, direct measurement of particle acidity is difficult because of its low water content and nanoscale particle size, thus proxy methods and parameters, such as the in situ acidity, strong acidity and ion-balanced acidity are used for its estimation (Zhang et al., 2008; He et al., 2011; Kerminen et al., 2001; Tian et al., 2018). Recently, Tian et al. (2018) reported that charge equivalent ratio between measured cations to anions $\left(R_{\mathrm{CE} / \mathrm{AE}}\right)$ is a good measure of acidity in fine-mode aerosol, because the temporal trend between $R_{\mathrm{CE} / \mathrm{AE}}$ and in situ $\mathrm{pH}$ 
was observed to be similar. He et al. (2015) also used the equivalent charge ratio and showed similar seasonal variation in in situ $\mathrm{PM}_{2.5}$ acidity and $R_{\mathrm{CE} / \mathrm{AE}}$, and the field observations have showed a general higher particle acidity in South China than North China. Moreover, an investigation conducted in four major cities of China by calculating the equivalent ratio of $\mathrm{NH}_{4}{ }^{+}$to the sum of $\mathrm{SO}_{4}{ }^{2-}$ plus $\mathrm{NO}_{3}{ }^{-}$during summertime indicated that the particle acidity was mostly dependent on the environmental SNA abundance (Pathak et al., 2009).

In this study, we estimated the particle acidity by calculating $\mathrm{RCE} / \mathrm{AE}$ in both sums of fine- and coarse-mode particles, and the results indicated that the fine particles are more acidic $(\mathrm{RCE} / \mathrm{AE}<1)$ than coarse particles $(\mathrm{RCE} / \mathrm{AE}>1)$ in Chengdu (Fig. 3). Since $\mathrm{SO}_{4}{ }^{2-}$ and $\mathrm{NO}_{3}{ }^{-}$are dominant ions in $\mathrm{PM}_{2.1}$, it is likely that the ambient $\mathrm{NH}_{3}$ was insufficient to completely neutralize the $\mathrm{H}_{2} \mathrm{SO}_{4}$ and $\mathrm{HNO}_{3}$ acids, despite the significantly high loading of $\mathrm{NH}_{4}{ }^{+}$. While in coarse particles, the $\mathrm{SO}_{4}{ }^{2-}, \mathrm{Ca}^{2+}$ and $\mathrm{NO}_{3}{ }^{-}$accounted for $76 \%$ of the total WSIIs, in which the $\mathrm{Ca}^{2+}$ was excess to integrate with $\mathrm{SO}_{4}{ }^{2-}$ and $\mathrm{NO}_{3}{ }^{-}$(He et al., 2012; Chen et al., 2015; Huang et al., 2018). However, two anomalous high $\mathrm{RCE} / \mathrm{AE}$ values (i.e., > 1) of fine particles were observed in May and July of 2012, when the $\mathrm{PM}_{2.1} / \mathrm{PM}_{11}$ ratios were high (Fig. 1), which can be ascribed to the influence from biomass burning episodes that contribute the large amount of cations (e.g., $\mathrm{NH}_{4}^{+}, \mathrm{K}^{+}$, and $\mathrm{Na}^{+}$). The decrease trend of $R_{\mathrm{CE} / \mathrm{AE}}$ for fine particles from spring to winter was likely associated with the more intensive emission and conversion of anthropogenic acidic species (e.g., $\mathrm{SO}_{2}$ and $\mathrm{NO}_{x}$ ) (Kerminen et al., 2001; Tian et al., 2018).

\section{Implications for $\mathrm{SO}_{4}{ }^{2-}$ and $\mathrm{NO}_{3}^{-}$Pollution}

The A/S ratios in PM were found to be 1.79, 1.33, 1.19 and 1.14 in winter, spring, summer and autumn, respectively, at Chengdu. According to the threshold value of A/S (1.5) suggested by Pathak et al. (2004, 2009), it is clear that the " $\mathrm{NH}_{3}$-rich" and " $\mathrm{NH}_{3}$-poor" atmospheres prevailed in winter and all other three seasons, respectively. Hence, the $\mathrm{NO}_{3}{ }^{-}$in fine-mode particles at Chengdu should have been formed through heterogeneous reactions during spring to autumn. Whereas in winter, it might have been generated by homogeneous gas-phase reactions of $\mathrm{HNO}_{3}$ with $\mathrm{NH}_{3}$, because the rate may be much higher for the formation of $\mathrm{NH}_{4} \mathrm{NO}_{3}$ rather than the neutralization rate of $\mathrm{H}_{2} \mathrm{SO}_{4}$ by ambient $\mathrm{NH}_{3}$ (Huang et al., 2011; Tian et al., 2018). Additionally, the size distribution of $\mathrm{NO}_{3}{ }^{-}$in Fig. 2(b) may be partially interpreted by the seasonal $\mathrm{A} / \mathrm{S}$ values obtained, such as the minor coarse-mode peaks could be associated with $\mathrm{Ca}\left(\mathrm{NO}_{3}\right)_{2}$ or $\mathrm{Mg}\left(\mathrm{NO}_{3}\right)_{2}$, which were heterogeneously formed on pre-existed soil particles (Zhuang et al., 1999; Li et al., 2018).

We also calculated the $\left[\mathrm{NO}_{3}{ }^{-}\right] /\left[\mathrm{SO}_{4}{ }^{2-}\right]$ mass ratios in both fine and coarse fractions in each season. Their averages were generally less than 1 (Figs. 3(d)-3(e)), indicating higher contribution from stationary sources emissions than that from mobile sources at Chengdu (Yao et al., 2002). Average coarse-mode $\left[\mathrm{NO}_{3}{ }^{-}\right] /\left[\mathrm{SO}_{4}{ }^{2-}\right]$ in warm seasons (i.e., 0.84 and 0.54 during spring and summer, respectively) were significantly higher than that of fine mode $(0.43$ and 0.27 , respectively), but it was the opposite in cold seasons ( 0.59 and 0.68 in fine mode and 0.58 and 0.43 in coarse mode in
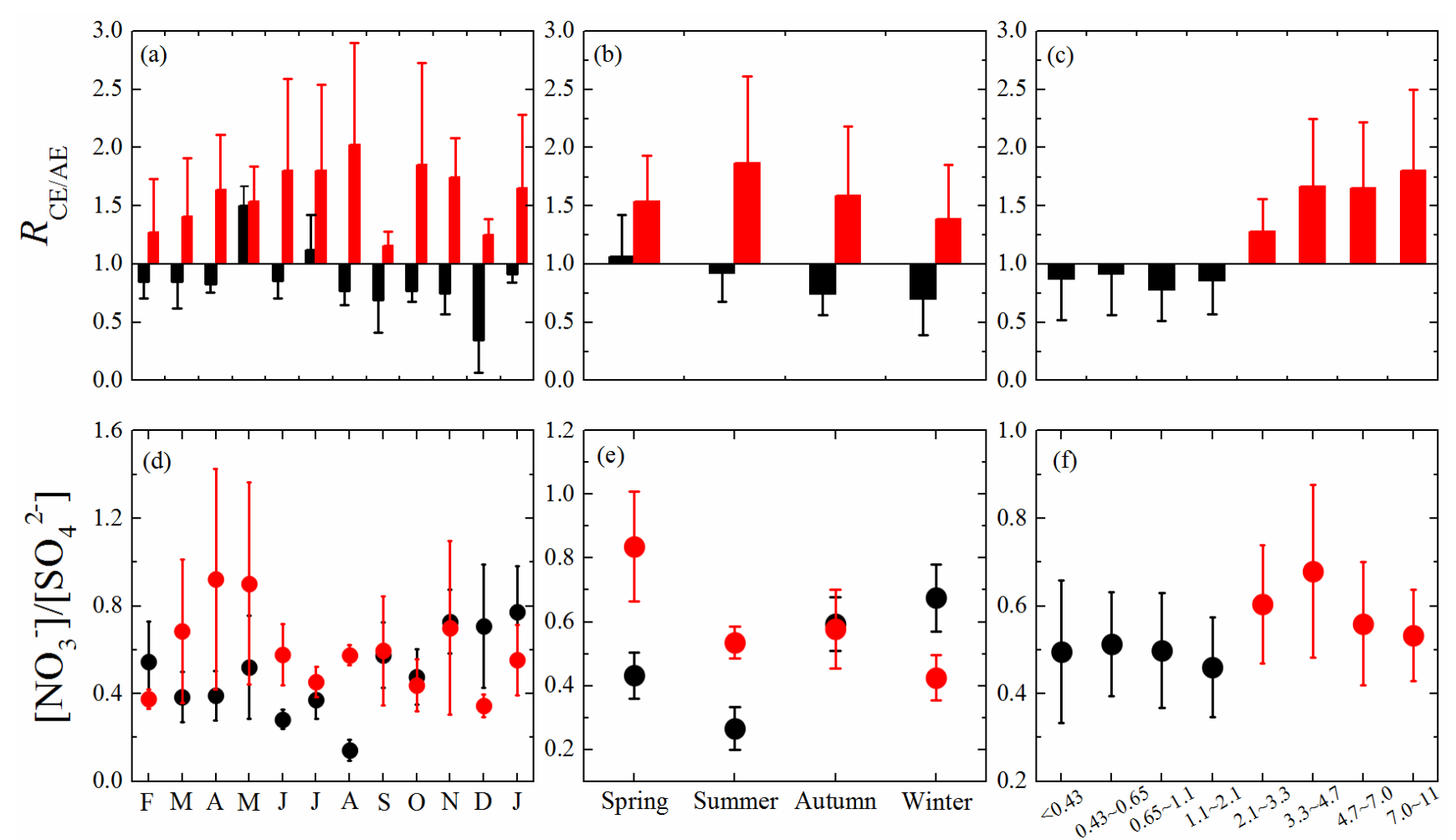

Fig. 3. The $R_{\mathrm{CE} / \mathrm{AE}}$ and $\mathrm{NO}_{3}{ }^{-} / \mathrm{SO}_{4}{ }^{2-}$ molar ratios in (a and d) different months and (b and e) seasons, and (c and $\mathrm{f}$ ) size ranges, respectively (red for coarse-mode particles; black for fine-mode particles). 
autumn and winter, respectively). Based on hourly measurements of acidic gases, ammonia and secondary inorganic aerosols in a tropical urban atmosphere, Behera et al. (2013) reported that the conversion of $\mathrm{SO}_{2}$ into $\mathrm{SO}_{4}{ }^{2-}$ and $\mathrm{HNO}_{3}$ into $\mathrm{NO}_{3}{ }^{-}$was sensitive to the changes in temperature and relative humidity, respectively. However, due to the existence of thermodynamic equilibrium between precursor gases and fine particle $\mathrm{NH}_{4}^{+}$salts (e.g., $\mathrm{NH}_{4} \mathrm{NO}_{3}$ ), the conversion of $\mathrm{HNO}_{3}$ into $\mathrm{NO}_{3}{ }^{-}$may also be sensitive to the changes in temperature, but the $\mathrm{Ca}\left(\mathrm{NO}_{3}\right)_{2}$ or $\mathrm{Mg}\left(\mathrm{NO}_{3}\right)_{2}$ in coarse mode were supposed to be less sensitive to the variations in the temperature (Zhuang et al., 1999; Zhang et al., 2008; He et al., 2012). Moreover, the formation of aerosol $\mathrm{NO}_{3}{ }^{-}$could also be influenced by the ambient $\mathrm{NH}_{3}$ content (Pathak et al., 2004, 2009; Huang et al., 2011). Therefore, we infer that the size and seasonal distributions of aerosol $\left[\mathrm{NO}_{3}{ }^{-}\right] /\left[\mathrm{SO}_{4}{ }^{2-}\right]$ at Chengdu were driven by the conversion of gaseous precursors and meteorological conditions (Zhuang et al., 1999; Guo et al., 2010; Huang et al., 2016). Besides, the annual averages of fine-mode $\left[\mathrm{NO}_{3}{ }^{-}\right] /\left[\mathrm{SO}_{4}{ }^{2-}\right]$ were lower than that of coarse-mode particles (Fig. 3(f)), indicating the high abundance of coarse-mode $\mathrm{NO}_{3}{ }^{-}$and fine-mode $\mathrm{SO}_{4}{ }^{2}$ resulted due to the prevailing $\mathrm{NH}_{3}$-poor atmosphere at Chengdu (Pathak et al., 2009).

The scatter plots of the molar concentration of $\mathrm{NO}_{3}{ }^{-}$and $\mathrm{NO}_{3}{ }^{-} / \mathrm{SO}_{4}{ }^{2-}(\mathrm{N} / \mathrm{S})$ molar ratios as a function of $\mathrm{A} / \mathrm{S}$ ratios in each season are illustrated in Fig. 4. Correlation between $\mathrm{A} / \mathrm{S}$ and $\mathrm{NO}_{3}{ }^{-}$found to be positive and significant $(p<0.01)$ in spring and winter $(p<0.01)$. It implies that the formation of $\mathrm{NO}_{3}{ }^{-}$is increased with the increase of $\mathrm{A} / \mathrm{S}$. However, the molar concentrations of $\mathrm{NO}_{3}{ }^{-}$were comparable in each and every season, suggesting that $\mathrm{NH}_{3}$ might have played a critical role in altering the heterogeneous and homogeneous formation process of aerosol $\mathrm{NO}_{3}^{-}$, depending on its availability, $\mathrm{NH}_{3}$-poor and -rich atmosphere, respectively (Pathak et al., 2009; Huang et al., 2018). This result is consistent with the results obtained by Weber et al. (2016) that the aerosol $\mathrm{NH}_{4} \mathrm{NO}_{3}$ concentrations increase with decreasing $\mathrm{SO}_{4}{ }^{2-}$ in the steady-state $\mathrm{NH}_{3}$ atmosphere of southeastern United States. Whereas the linear relations between $\mathrm{A} / \mathrm{S}$ and $\mathrm{N} / \mathrm{S}$ molar ratio were positive and negative in winter $(0.01<p<0.05)$ and spring $(p<0.001)$, respectively (Fig. 4(b)). These relations together with the significant positive correlations between $\mathrm{A} / \mathrm{S}$ and $\mathrm{NO}_{3}{ }^{-}$molar concentration in winter and spring (Fig. 6(a)) imply that the formation of $\mathrm{NO}_{3}{ }^{-}$was more influenced than that of $\mathrm{SO}_{4}{ }^{2-}$ formation with the increase in $\mathrm{A} / \mathrm{S}$ in winter, when the formation of $\mathrm{SO}_{4}{ }^{2-}$ come to its limited regimes relative to the $\mathrm{NH}_{3}$ content, yet the $\mathrm{HNO}_{3(\mathrm{~g})}$ become available for $\mathrm{NH}_{3}$ to form the aerosol $\mathrm{NO}_{3}{ }^{-}$predominantly (Huang et al., 2011; Tian et al., 2018). In addition, the previous studies also indicated that the low temperature is favorable for the formation of $\mathrm{NO}_{3}{ }^{-}$but not for the $\mathrm{SO}_{4}{ }^{2-}$ (Guo et al., 2010; Huang et al., 2016;). Thus, the formation of $\mathrm{NO}_{3}{ }^{-}$could be more efficient than $\mathrm{SO}_{4}{ }^{2-}$ during cold and $\mathrm{NH}_{3}$-rich atmosphere in winter.

In contrast, aerosol $\mathrm{SO}_{4}{ }^{2-}$ might have more efficiently formed from homogeneous gas-phase reactions of $\mathrm{H}_{2} \mathrm{SO}_{4}$ and $\mathrm{NH}_{3}$ than aerosol $\mathrm{NO}_{3}{ }^{-}$with the increase in $\mathrm{A} / \mathrm{S}$ in spring in $\mathrm{NH}_{3}$-poor and dry atmosphere (Table 1). It is likely
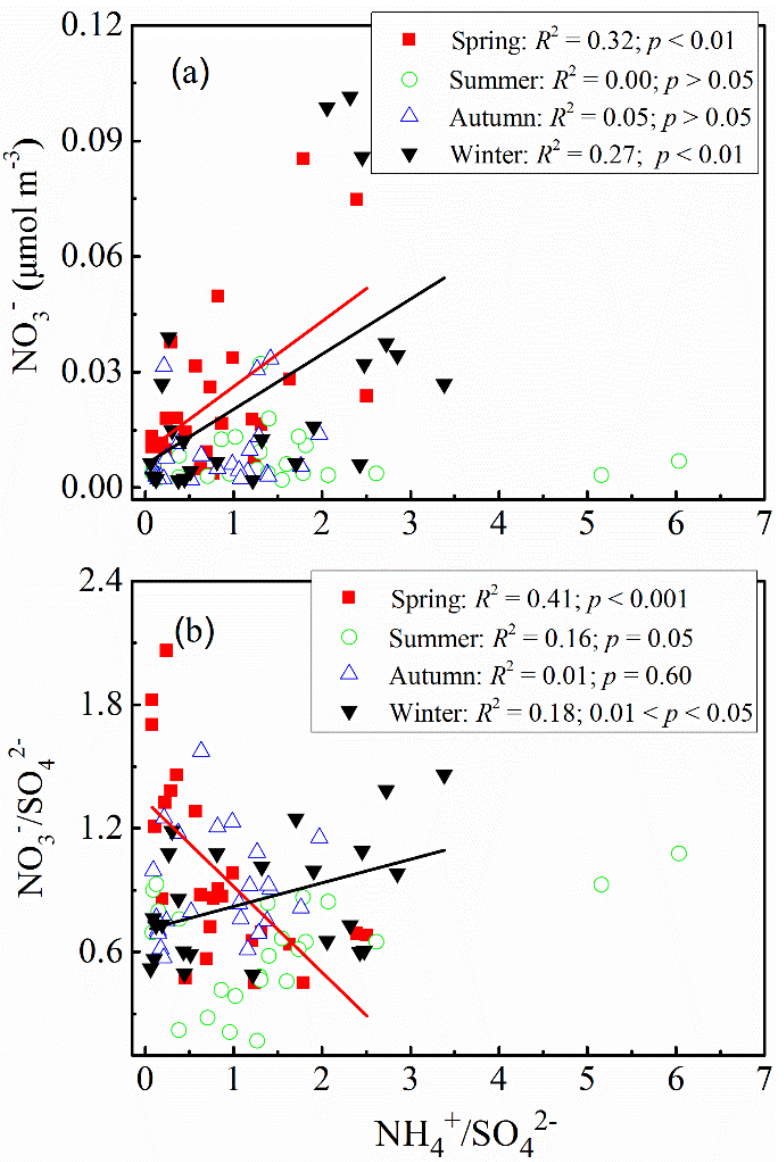

Fig. 4. Scatter plots of (a) $\mathrm{NO}_{3}{ }^{-}$molar concentration and (b) $\mathrm{NO}_{3}{ }^{-} / \mathrm{SO}_{4}{ }^{2-}$ molar ratios as a function of $\mathrm{NH}_{4}{ }^{+} / \mathrm{SO}_{4}{ }^{2-}$ molar ratios over the four sampling seasons $(n=24$ for each season).

because the kinetic rate of neutralization of $\mathrm{H}_{2} \mathrm{SO}_{4}$ by $\mathrm{NH}_{3}$ could be significantly higher than forming aerosol $\mathrm{NO}_{3}{ }^{-}$in $\mathrm{NH}_{3}$-poor atmosphere (Huang et al., 2011), whereas the $\mathrm{NO}_{3}{ }^{-}$formation could occur from the hydrolysis of $\mathrm{N}_{2} \mathrm{O}_{5}$ under high relative humidity (Pathak et al., 2009). Furthermore, the low relative humidity in spring might have promoted the heterogeneous reaction of $\mathrm{HNO}_{3}$ on soil dust particles, one of the formation pathways of aerosol $\mathrm{NO}_{3}^{-}$, at Chengdu (Pathak et al., 2011). According to the lower A/S $(<1.5)$ and higher $R_{\mathrm{CE} / \mathrm{AE}}(>1)$ values, the nonvolatile cations from minerals could have played a vital role in forming the particles in spring at Chengdu, and this can also be evidenced by the $\mathrm{PM}_{2.1} / \mathrm{PM}_{11}$ ratio shows in Fig. 1. In Fig. 3(e), as the coarsemode N/S is significantly higher than fine-mode particles in spring, the $\mathrm{NO}_{3}^{-}$were supposed to be formed on the minerals, through heterogeneous reactions, and mainly in the forms of $\mathrm{Mg}\left(\mathrm{NO}_{3}\right)_{2}$ or $\mathrm{Ca}\left(\mathrm{NO}_{3}\right)_{2}$. Otherwise, only several minor peaks for $\mathrm{SO}_{4}{ }^{2-}$ are shown in coarse mode, while the finemode $\mathrm{SO}_{4}{ }^{2-}$ is likely to be formed more efficiently than $\mathrm{NO}_{3}{ }^{-}$ in spring with the increase in A/S (Fig. 4). On the other hand, the correlations are insignificant in summer and winter, and this might principally be ascribed to the high rainfall, which greatly impacts the WSII loading in the atmosphere (Pan et al., 2017). 


\section{CONCLUSIONS}

The characteristics of WSIIs in size-segregated particles in urban Chengdu were investigated over a one-year period. The results showed that the WSIIs were more enriched in the fine particles than the coarse ones, and $\mathrm{NH}_{4}{ }^{+}, \mathrm{SO}_{4}{ }^{2-}$, and $\mathrm{NO}_{3}{ }^{-}$, the dominant WSIIs in the fine fraction, were mostly generated by the conversion of anthropogenic gaseous precursors, especially during the cold seasons. The calculated equivalent ratios $\left(R_{\mathrm{CE} / \mathrm{AE}}\right)$ indicated that the fine particles were more acidic $(<1)$ than the coarse particles $(>1)$. Furthermore, the $\mathrm{NH}_{4}{ }^{+} / \mathrm{SO}_{4}{ }^{2-}(\mathrm{A} / \mathrm{S})$ molar ratio in the finemode $\mathrm{PM}$ suggested that the atmosphere was $\mathrm{NH}_{3}$-poor during spring, summer, and autumn but $\mathrm{NH}_{3}$-rich during winter; therefore, the $\mathrm{NO}_{3}{ }^{-}$in the fine fraction was formed homogeneously during winter and heterogeneously during the other three seasons. Based on the positive correlations between the $\mathrm{A} / \mathrm{S}$ and $\mathrm{NO}_{3}{ }^{-}$molar concentrations observed during spring and winter, the increase in $\mathrm{NH}_{3}$ or $\mathrm{NH}_{4}^{+}$may enhance the formation of $\mathrm{NO}_{3}{ }^{-}$in aerosols, but certain meteorological conditions, such as high temperatures and concentrated rainfall, significantly disrupt this relationship. Finally, we infer from the seasonal correlations between the $\mathrm{A} / \mathrm{S}$ and $\mathrm{NO}_{3}{ }^{-} / \mathrm{SO}_{4}{ }^{2-}$ molar ratios in addition to the temporal variation in the $\mathrm{NO}_{3}{ }^{-} / \mathrm{SO}_{4}{ }^{2-}$ molar ratio that the $\mathrm{NH}_{3}$-rich atmosphere during winter favors the formation of $\mathrm{NO}_{3}$ rather than $\mathrm{SO}_{4}{ }^{2-}$, whereas the $\mathrm{NH}_{3}$-poor atmosphere during spring favors the formation of the latter, as the heterogeneous formation of the former during this season is less efficient.

\section{ACKNOWLEDGEMENTS}

This work was supported by the National Natural Science Foundation of China (Grant No. 41173022 and 41773006) and Natural Science Foundation of Tianjin (Grant No. 17JCZDJC39400). We also appreciate Ph.D. Jing Yu and Long Lv for helping field particulate matter sampling.

\section{REFERENCES}

Behera, S.N., Betha, R. and Balasubramanian, R. (2013). Insights into chemical coupling among acidic gases, ammonia and secondary inorganic aerosols. Aerosol Air Qual. Res. 13: 1282-1296.

Carpenter, R. (1969). Factors controlling the marine geochemistry of fluorine. Geochim. Cosmochim. Acta 33: 1153-1167.

Chen, Y. and Xie, S.D. (2013). Long-term trends and characteristics of visibility in two megacities in southwest China: Chengdu and Chongqing. J. Air Waste Manage. Assoc. 63: 1058-1069.

Chen, Y. and Xie, S.D. (2014). Characteristics and formation mechanism of a heavy air pollution episode caused by biomass burning in Chengdu, Southwest China. Sci. Total Environ. 473-474: 507-517.

Chen, Y., Luo, B. and Xie, S.D. (2015). Characteristics of the long-range transport dust events in Chengdu, Southwest China. Atmos. Environ. 122: 713-722.

Dockery, D.W., Pope, C.A., Xu, X., Spengler, J.D., Ware,
J.H., Fay, M.E., Ferris, B.G. Jr. and Speizer, F.E. (1993). An association between air pollution and mortality in six U. S. cities. N. Engl. J. Med. 329: 1753-1759.

Guo, S., Hu, M., Wang, Z.B., Slanina, J. and Zhao, Y.L. (2010). Size-resolved aerosol water-soluble ionic compositions in the summer of Beijing: Implication of regional secondary formation. Atmos. Chem. Phys. 10: 947-959.

He, K., Zhao, Q., Ma, Y., Duan, F., Yang, F., Shi, Z. and Chen, G. (2012). Spatial and seasonal variability of $P_{2.5}$ acidity at two Chinese megacities: Insights into the formation of secondary inorganic aerosols. Atmos. Chem. Phys. 12: 1377-1395.

Hennigan, C.J., Izumi, J., Sullivan, A.P., Weber, R.J. and Nenes, A. (2014). A critical evaluation of proxy methods used to estimate the acidity of atmospheric particles. Atmos. Chem. Phys. 14: 2775-2790.

Huang, R.J., Zhang, Y., Bozzetti, C., Ho, K.F., Cao, J.J., Han, Y., Daellenbach, K.R., Slowik, J.G., Platt, S.M., Canonaco, F., Zotter, P., Wolf, R., Pieber, S.M., Bruns, E.A., Crippa, M., Ciarelli, G., Piazzalunga, A., Schwikowski, M., Abbaszade, G., Schnelle-Kreis, J., Zimmermann, R., An, Z., Szidat, S., Baltensperger, U., El Haddad, I. and Prévôt, A.S. (2014). High secondary aerosol contribution to particulate pollution during haze events in China. Nature 514: 218-222.

Huang, X., Liu, Z., Zhang, J., Wen, T., Ji, D. and Wang, Y. (2016). Seasonal variation and secondary formation of size-segregated aerosol water-soluble inorganic ions during pollution episodes in Beijing. Atmos. Res. 168: 7079.

Huang, X., Zhang, J., Luo, B., Wang, L., Tang, G., Liu, Z., Song, H., Zhang, W., Yuan, L. and Wang, Y. (2018). Water-soluble ions in $\mathrm{PM}_{2.5}$ during spring haze and dust periods in Chengdu, China: Variations, nitrate formation and potential source areas. Environ Pollut. 243: 17401749.

IPCC (2013). Climate Change 2013: The Physical Science Basis. Contribution of Working Group I to the Fifth Assessment Report of the Intergovernmental Panel on Climate Change, Stocker, T.F., Qin, D., Plattner, G.K., et al. (Eds.), Cambridge University Press, doi: 10.1017/CB O9781107415324.016.

Jayarathne, T., Stockwell, C.E., Yokelson, R.J., Nakao, S. and Stone, E. (2014). Emissions of Fine Particle Fluoride from Biomass Burning. Environ. Sci. Technol. 48: 12636-12644.

Jiang, F., Liu, F., Lin, Q., Fu, Y., Yang, Y., Peng, L., Lian, X., Zhang, G., Bi, X., Wang, X. and Sheng, G. (2019). Characteristics and formation mechanisms of sulfate and nitrate in size-segregated atmospheric particles from urban Guangzhou, China. Aerosol Air Qual. Res. 19: 1284-1293

Kalinić, N., Vağić, V., Hršak, J. and Lambaša-Belak, Ž. (1997). Fluoride mass concentrations in the air at different distances from an aluminum factory. Environ. Res. Forum. 7-8: 253-257.

Kerminen, V.M., Hillamo, R., Teinilä, K., Pakkanen, T., Allegrini, I. and Sparapani, R. (2001). Ion balances of size-resolved tropospheric aerosol samples: Implications for the acidity and atmospheric processing of aerosols. 
Atmos. Environ. 35: 5255-5265.

Klimont, Z., Kupiainen, K., Heyes, C., Purohit, P., Cofala, J., Rafaj, P., Borken-Kleefeld, J. and Schöpp, W. (2017). Global anthropogenic emissions of particulate matter including black carbon. Atmos. Chem. Phys. 17: 86818723.

Kulmala, M., Vehkamäki, H., Petäjä, T., Dal Maso, M., Lauri, A., Kerminen, V.M., Birmili, W. and McMurry, P.H. (2004). Formation and growth rates of ultrafine atmospheric particles: A review of observations. $J$. Aerosol Sci. 35: 143-176.

Li, W.J. and Shao, L.Y. (2009). Observation of nitrate coatings on atmospheric mineral dust particles. Atmos. Chem. Phys. 9: 1863-1871.

Li, X.D., Yang, Z., Fu, P., Yu, J., Lang, Y.C., Liu, D., Ono, K. and Kawamura, K. (2015). High abundances of dicarboxylic acids, oxocarboxylic acids, and $\alpha$ dicarbonyls in fine aerosols $\left(\mathrm{PM}_{2.5}\right)$ in Chengdu, China during wintertime haze pollution. Environ. Sci. Pollut. Res. 22: 12902-12918.

Li, Y., Hao, Q., Wen, T., Ji, D., Liu, Z., Wang, Y., Li, X., He, X. and Jiang, C. (2018). Pollution characteristics of water-soluble ions in aerosols in the urban area in Beibei of Chongqing. Aerosol Air Qual. Res. 18: 1531-1544.

Lin, Y.C., Cheng, M.T., Ting, W.Y. and Yeh, C.R. (2006). Characteristics of Gaseous $\mathrm{HNO}_{2}, \mathrm{HNO}_{3}, \mathrm{NH}_{3}$ and particulate ammonium nitrate in an urban city of central Taiwan. Atmos. Environ. 40: 4725-4733.

Lin, Y.C. and Cheng, M.T. (2007). Evaluation of formation rates of $\mathrm{NO}_{2}$ to gaseous and particulate nitrate in the urban atmosphere. Atmos. Environ. 41: 1903-1910.

Liu, X., Sun, K., Qu, Y., Hu, M., Sun, Y., Zhang, F. and Zhang, Y. (2015). Secondary formation of sulfate and nitrate during a haze episode in megacity Beijing, China. Aerosol Air Qual. Res. 15: 2246-2257.

Ning, G., Wang, S., Yim, S.H.L., Li, J., Hu, Y., Shang, Z., Wang, J. and Wang, J. (2018). Impact of low-pressure systems on winter heavy air pollution in the northwest Sichuan Basin, China. Atmos. Chem. Phys. 18: 1360113615.

Pan, Y.P., Zhu, X.Y., Tian, S.L., Wang, L.L., Zhang, G.Z., Zhou, Y.B., Xu, P., Hu, B. and Wang, Y.S. (2017). Wet deposition and scavenging ratio of air pollutants during an extreme rainstorm in the north china plain. Atmos. Oceanic Sci. Lett. 10: 348-353.

Pathak, R.K., Yao, X.H. and Chan, C.K. (2004). Sampling artifacts of acidity and ionic species in $\mathrm{PM}_{2.5}$. Environ. Sci. Technol. 38: 254-259.

Pathak, R.K., Wu, W.S. and Wang, T. (2009). Summertime $\mathrm{PM}_{2.5}$ ionic species in four major cities of China: Nitrate formation in an ammonia-deficient atmosphere. Atmos. Chem. Phys. 9: 1711-1722.

Pathak, R.K. Wang, T. and Wu, W.S. (2011). Nighttime enhancement of $\mathrm{PM}_{2.5}$ nitrate in ammonia-poor atmospheric conditions in Beijing and Shanghai: Plausible contributions of heterogeneous hydrolysis of $\mathrm{N}_{2} \mathrm{O}_{5}$ and $\mathrm{HNO}_{3}$ partitioning. Atmos. Environ. 45: 1183-1191.

Shi, G.L., Tian, Y.Z., Ma, T., Song, D.L., Zhou, L.D., Han, B., Feng, Y.C. and Russell, A.G. (2017). Size distribution, directional source contributions and pollution status of PM from Chengdu, China during a long-term sampling campaign. J. Environ. Sci. (China) 56: 1-11.

Steinfeld, J.I. (1998). Atmospheric chemistry and physics: From air pollution to climate change. Environ. Sci. Policy Sustainable Dev. 40: 26-26.

Tao, J., Zhang, L., Engling, G., Zhang, R., Yang, Y., Cao, J., Zhu, C., Wang, Q. and Luo, L. (2013). Chemical composition of $\mathrm{PM}_{2.5}$ in an urban environment in Chengdu, China: Importance of springtime dust storms and biomass burning. Atmos. Res. 122: 270-283.

Tao, J., Gao, J., Zhang, L., Zhang, R., Che, H., Zhang, Z., Lin, Z., Jing, J., Cao, J. and Hsu, SC. (2014). PM $_{2.5}$ pollution in a megacity of southwest China: Source apportionment and implication. Atmos. Chem. Phys. 14: 8679-8699.

Tian, S.L., Pan, Y.P. and Wang, Y.S. (2016a). Size-resolved source apportionment of particulate matter in urban Beijing during haze and non-haze episodes. Atmos. Chem. Phys. 16: 1-19.

Tian, S.L., Pan, Y.P. and Wang, Y.S. (2018). Ion balance and acidity of size-segregated particles during haze episodes in urban Beijing. Atmos. Res. 201: 159-167.

Tian, Y.Z., Wu, J.H., Shi, G.L., Wu, J.Y., Zhang, Y.F., Zhou, L.D., Zhang, P. and Feng, Y.C. (2013). Long-term variation of the levels, compositions and sources of sizeresolved particulate matter in a megacity in China. Sci. Total Environ. 463-464: 462-468.

Tian, Y.Z., Shi, G.L., Huang-Fu, Y.Q., Song, D.L., Liu, J.Y., Zhou, L.D. and Feng, Y.C. (2016b) Seasonal and regional variations of source contributions for $\mathrm{PM}_{10}$ and $\mathrm{PM}_{2.5}$ in urban environment. Sci. Total Environ. 557-558: 697704.

Vieira-Filho, M., Pedrotti, J.J. and Fornaro, A. (2016). Water-soluble ions species of size-resolved aerosols: Implications for the atmospheric acidity in São Paulo megacity, Brazil. Atmos. Res. 181: 281-287.

Wang, G., Huang, L., Gao, S., Gao, S. and Wang, L. (2002). Characterization of water-soluble species of $\mathrm{PM}_{10}$ and $\mathrm{PM}_{2.5}$ aerosols in urban area in Nanjing, China. Atmos. Environ. 36: 1299-1307.

Wang, G., Zhang, R., Gomez, M.E., Yang, L., Levy Zamora, M., Hu, M., Lin, Y., Peng, J., Guo, S., Meng, J., Li, J., Cheng, C., Hu, T., Ren, Y., Wang, Y., Gao, J., Cao, J., An, Z., Zhou, W., Li, G., Wang, J., Tian, P., MarreroOrtiz, W., Secrest, J., Du, Z., Zheng, J., Shang, D., Zeng, L., Shao, M., Wang, W., Huang, Y., Wang, Y., Zhu, Y., Li, Y., Hu, J., Pan, B., Cai, L., Cheng, Y., Ji, Y., Zhang, F., Rosenfeld, D., Liss, P.S., Duce, R.A., Kolb, C.E. and Molina, M.J. (2016). Persistent sulfate formation from London Fog to Chinese haze. Proc. Natl. Acad. Sci. U.S.A. 113: 13630-13635.

Wang, J., Hu, Z., Chen, Y., Chen, Z. and Xu, S. (2013a). Contamination characteristics and possible sources of $\mathrm{PM}_{10}$ and $\mathrm{PM}_{2.5}$ in different functional areas of Shanghai, China. Atmos. Environ. 68: 221-229.

Wang, J., Zhang, J.S., Liu, Z.J., Wu, J.H., Zhang, Y.F., Han, S.Q., Zheng, X.J., Zhou, L.D., Feng, Y.C. and Zhu, T. (2017a). Characterization of chemical compositions in 
size-segregated atmospheric particles during severe haze episodes in three mega-cities of China. Atmos. Res. 187: 138-146.

Wang, L., Ji, D., Li, Y., Gao, M., Tian, S., Wen, T., Liu, Z., Wang, L., Xu, P., Jiang, C. and Wang, Y. (2017b). The impact of relative humidity on the size distribution and chemical processes of major water-soluble inorganic ions in the megacity of Chongqing, China. Atmos. Res. 192: 19-29.

Wang, P., Cao, J., Tie, X., Wang, G., Li, G., Hu, T., Wu, Y., Xu, Y., Xu, G., Zhao, Y., Ding, W., Liu, H. and Huang, R. (2015). Impact of meteorological parameters and gaseous pollutants on $\mathrm{PM}_{2.5}$ and $\mathrm{PM}_{10}$ mass concentrations during 2010 in Xi'an, China. Aerosol Air Qual. Res. 15: 18441854.

Wang, Q., Cao, J., Shen, Z., Tao, J., Xiao, S., Luo, L., He, Q. and Tang, X. (2013b). Chemical characteristics of $\mathrm{PM}_{2.5}$ during dust storms and air pollution events in Chengdu, China. Particuology 11: 70-77.

Wang, S., Yu, S., Yan, R., Zhang, Q., Li, P., Wang, L., Liu, W. and Zheng, X. (2017a). Characteristics and origins of air pollutants in Wuhan, China, based on observations and hybrid receptor models. J. Air Waste Manage. Assoc. 67: 739-753.

Wang, X., Bi, X., Sheng, G. and Fu, J. (2006). Chemical composition and sources of $\mathrm{PM}_{10}$ and $\mathrm{PM}_{2.5}$ aerosols in Guangzhou, China. Environ. Monit. Assess. 119: 425439.

Wang, Y., Zhuang, G.S., Tang, A., Yuan, H., Sun, Y.L., Chen, S. and Zhang, A. (2005). The ion chemistry and the source of $\mathrm{PM}_{2.5}$ aerosol in Beijing. Atmos. Environ. 39: 3771-3784.

Weber, R.J., Guo, H., Russell, A.G. and Nenes, A. (2016). High aerosol acidity despite declining atmospheric sulfate concentrations over the past 15 years. Nat. Geosci. 9: 282-285.

West, J.J., Cohen, A., Dentener, F., Brunekreef, B., Zhu, T., Armstrong, B., Bell, M.L., Brauer, M., Carmichael, G., Costa, D.L., Dockery, D.W., Kleeman, M., Krzyzanowski, M., Künzli, N., Liousse, C., Lung, S.C., Martin, R.V., Pöschl, U., Pope, C.A., Roberts, J.M., Russell, A.G. and Wiedinmyer, C. (2016). What we breathe impacts our health: Improving understanding of the link between air pollution and health. Environ. Sci. Technol. 50: 48954904.

WHO (2006). WHO Air quality guidelines for particulate matter, ozone, nitrogen dioxide and sulfur dioxide: Global update 2005: Summary of risk assessment. No. WHO/SDE/PHE/OEH/06.02. World Health Organization, Geneva.

WHO (2013). Review of evidence on health aspects of air pollution-REVIHAAP Project. World Health Organization, WHO Regional Office for Europe, Copenhagen.

Wu, P., Huang, X., Zhang, J., Luo, B., Luo, J., Song, H., Zhang, W., Rao, Z., Feng, Y. and Zhang, J. (2018).
Characteristics and formation mechanisms of autumn haze pollution in Chengdu based on high time-resolved water-soluble ion analysis. Environ. Sci. Pollut. Res. 26: 2649-2661.

Wu, X., Deng, J., Chen, J., Hong, Y., Xu, L., Yin, L., Du, W., Hong, Z., Dai, N. and Yuan, C.S. (2017). Characteristics of water-soluble inorganic components and acidity of $\mathrm{PM}_{2.5}$ in a coastal city of China. Aerosol Air Qual. Res. 17: 2152-2164.

Xiao, H.Y. and Liu, C.Q. (2004). Chemical characteristics of water-soluble components in TSP over Guiyang, SW China. Atmos. Environ. 38: 6297-6306.

Yang, F., Tan, J., Zhao, Q., Du, Z., He, K., Ma, Y., Duan, F., Chen, G. and Zhao, Q. (2011). Characteristics of $\mathrm{PM}_{2.5}$ speciation in representative megacities and across China. Atmos. Chem. Phys. 11: 5207-5219.

Yang, Z., Li, X.D., Deng, J. and Wang, H.Y. (2015). Stable sulfur isotope ratios and water-soluble inorganic compositions of $\mathrm{PM}_{10}$ in Yichang City, central China. Environ. Sci. Pollut. Res. Int. 22: 13564-13572.

Yao, L., Garmash, O., Bianchi, F., Zheng, J., Yan, C., Kontkanen, J., Junninen, H., Mazon, S.B., Ehn, M., Paasonen, P. and Sipilä, M. (2018). Atmospheric new particle formation from sulfuric acid and amines in a Chinese megacity. Science 361: 278-281.

Yao, X., Chan, C.K., Fang, M., Cadle, S., Chan, T., Mulawa, P., He, K. and Ye, B. (2002). The water-soluble ionic composition of $\mathrm{PM}_{2.5}$ in Shanghai and Beijing, China. Atmos. Environ. 36: 4223-4234.

Zhang, L., Vet, R., Wiebe, A., Mihele, C., Sukloff, B., Chan, E., Moran, M.D. and Iqbal, S. (2008). Characterization of the size-segregated water-soluble inorganic ions at eight Canadian rural sites. Atmos. Chem. Phys. 8: 7133-7151.

Zhang, R., Wang, G., Guo, S., Zamora, M.L., Ying, Q., Lin, Y., Wang, W., Hu, M. and Wang, Y. (2015). Formation of urban fine particulate matter. Chem. Rev. 115: 38033855.

Zhao, J., Zhang, F., Xu, Y. and Chen, J. (2011). Characterization of water-soluble inorganic ions in sizesegregated aerosols in coastal city, Xiamen. Atmos. Res. 99: 546-562.

Zhuang, H., Chan, C.K., Fang, M. and Wexler, A.S. (1999). Formation of nitrate and non-sea-salt sulfate on coarse particles. Atmos. Environ. 33: 4223-4233.

Zou, J., Liu, Z., Hu, B., Huang, X., Wen, T., Ji, D., Liu, J., Yang, Y., Yao, Q. and Wang, Y. (2018). Aerosol chemical compositions in the North China Plain and the impact on the visibility in Beijing and Tianjin. Atmos. Res. 201: 235-246.

Received for review, July 29, 2019 Revised, November 9, 2019 Accepted, November 10, 2019 